\title{
Spermidine Enhances Activities of Detoxification Enzymes in Onion (Allium cepa L.) Seedlings Under Short Term Salinity
}

\author{
Tanjina Islam 1, 2, Md. Ismail Hossain ${ }^{2}$, M. S. Rahaman ${ }^{3}$, Md. Motiar Rohman 1, * \\ ${ }^{1}$ Molecular Breeding Lab, Bangladesh Agricultural Research Institute, Gazipur, Bangladesh \\ ${ }^{2}$ Department of Horticulture, Sher-e-Bangla Agricultural University, Dhaka, Bangladesh \\ ${ }^{3}$ Department of Environmental Science, Stamford University, Dhaka, Bangladesh
}

Email address:

koly_357@yahoo.com@yahoo.com (T. Islam), ismail_sau@yahoo.com (M. I. Hossain), saidur_2006@yahoo.com (M. S. Rahaman), motiar_1@yahoo.com (M. M. Rohman)

${ }^{*}$ Corresponding author

\section{To cite this article:}

Tanjina Islam, Md. Ismail Hossain, M. S. Rahaman, Md. Motiar Rohman. Spermidine Enhances Activities of Detoxification Enzymes in Onion (Allium cepa L.) Seedlings Under Short Term Salinity. Cell Biology. Vol. 4, No. 3, 2016, pp. 18-23. doi: 10.11648/j.cb.20160403.11

Received: September 26, 2016; Accepted: October 10, 2016; Published: November 3, 2016

\begin{abstract}
In plant, glyoxalases [glyoxalase I (Gly-I, EC: 4.4.1.5) and glyoxalase II (Gly-II, EC: 3.1.2.6)] and glutathione $S$ transferase (GST, EC: 2.5.1.18) are major detoxification enzymes. On the other hand, spermidine (Spd) is important polyamine (PA) with significant role which interacts with stress protection mechanisms functioning in common against different types of stress. In this study, exogenous Spd was applied on onion seedlings to investigate its protective role through regulation of glyoxalase and GST activities. Continuous increase was observed in the content of methylglyoxal (MG) in onion leaves under salinity, and at 7 day of stress, MG contents increased by $260 \%$ over control. Application of Spd reduced the MG contents in saline treated seedlings through increasing glyoxalase mediated detoxification by 21 and $48 \%$ at 1 and 3 day of stress, respectively. Salinity increased Gly-I and Gly-II activities which was further increased by Spd upto 3 day of stress. On the other hand, salinity increased GST activity by 14, 55, 93 and 109\% over control at 1, 3,5 and 7 day, respectively. Application of Spd increased the activity in stressed seedlings at 3 day of stress while $21 \%$ higher activity was found. However, after 3 days, both glyoxalases and GST activities in Spd treated seedlings decreased and became almost similar to those in drought stressed seedlings without Spd. Considering the results, application of Spd in onion seedlings improved tolerance for short period of salinity.
\end{abstract}

Keywords: Spermidine, Glyoxalases, GST, Onion Seedlings

\section{Introduction}

Abiotic stress including salinity is one of the most important abiotic stress factors limiting plant growth and productivity of crops. Increased soil salinity has become an increasingly important topic globally. High exogenous salt concentrations cause ionic imbalance in the cells resulting in ion toxicity and osmotic stress [1,2]. Salinity mediated osmotic stress produces reactive oxygen species (ROS) such as superoxide radical $\left(\mathrm{O}_{2}{ }^{-}\right)$, singlet oxygen $\left({ }^{1} \mathrm{O}_{2}\right)$, hydroxyl radical $\left(\mathrm{OH}^{*}\right)$ and concomitantly hydrogen peroxide $\left(\mathrm{H}_{2} \mathrm{O}_{2}\right)$ $[3,4,5]$ and methylglyoxal (MG) $[6,7]$ in plant cells. ROS are highly reactive and toxic to plants and can lead to cell death by causing damage to proteins, lipids, DNA and carbohydrates $[5,8]$. At the same time, $\mathrm{MG}$ can react with and modify other molecules including DNA and proteins [6], whereas proteins being one of the major targets of ROS. Therefore, ROS and MG are highly toxic and must be detoxified by cellular responses, if the plant is to survive and grow [9].

Plants possess both non-enzymatic and enzymatic antioxidant defense systems against ROS [9, 10]. Among the non-enzymatic antioxidants, reduced glutathione (GSH) is the most abundant low molecular weight thiol in plants and plays an important role in the detoxification of ROS and MG 
[9]. Among the GSH dependent enzyme, glutathione $S$ transferases (GSTs) are an ancient and diverse group of multi-functional proteins that are widely distributed amongst living organisms. They can function as GSH transferases, GSH-dependent peroxidases, GSH-dependent isomerases and GSH-dependent oxidoreductases [11], as well as functioning as non-enzymatic carrier proteins and antioxidant recycling [12]. Up to 90 genes encoding GSTs are transcribed in different plant species, most of which are differentially induced by stress, and they play important parts in enzymatic thiol-dependent ROS scavenging mechanisms [13, 14, 15]. Importantly, after discovering of GST in maize in 1970, large number of studies was reported on vacuolar sequestration of endogenous substrates into vacuole $[16,17,18,19,20]$. On the other hand, in plants, the MG is detoxified mainly by glyoxalase system [6] which consists of two enzymes: glyoxalaseI (Gly-I) and glyoxalaseII (Gly-II). Gly-I uses reduced GSH to convert MG into S-D-lactoylglutathione (SLG). Then Gly-II converts SLG to D-lactate and one molecule of reduced glutathione is recycled back into the system [21]. A large number of research group reported the role of glyoxalases in plant responses to salt stress $[6,7,22$, 23, 24].

Polyamines (PAs), including the diamineputrescine (Put), triaminespermidine (Spd) and tetraminespermine (Spm) are ubiquitous low-molecular-weight aliphatic amines that are involved in regulation of plant growth and development [25] and are well known for their anti-senescence and anti-stress effects due to their acid neutralizing and antioxidant properties, as well as for their membrane and cell wall stabilizing abilities [26]. Because of their cationic nature at physiological $\mathrm{pH}$, PAs are able to interact with proteins, nucleic acids, membrane phospholipids and cell wall constituents, thereby stabilizing these molecules [27]. Apart from their implication in growth and development, PAs have been reported to be involved in defense response to biotic and abiotic stresses [28]. It has been shown that a high cellular level of PAs correlates with plant tolerance to a wide array of environmental stresses such as salinity [29], oxidative stress [30,31], low and high temperatures [32, 33, 34], hyperosmosis [35] and hypoxia [36]. Several biochemical and physiological effects were elicited by exogenously applied PAs including Spd under environmental stress. It was reported that exogenous Spd was effective in enhancing the activity of peroxidase under salinity stress and the salt-induced increase in reducing sugar and free proline level was further promoted by Spd in indica rice [37]. Moreover, it has been demonstrated that over expression of Spd synthase gene in transgenic Arabidopsis thaliana maintained higher levels of Spd content and enhanced tolerance to salinity, chilling, hyperosmosis and drought relative to the wild-type plants, which suggests that Spd plays an important role in stress signaling pathway as a signaling regulator, leading to build a stress tolerance mechanisms for plants [38]. However, effect of Spd in regulation of detoxification enzymes like glyoxalasea and GST. Moreover, onion possesses higher glyoxalase and GST activities [39].
Therefore, Spd might play important role in regulation of these enzymes under salinity stress and hence, this experiment were undertaken to examine the modulation of glyoxalases and GST in onion seedlings under salinity.

\section{Materials and Methods}

\subsection{Plant Materials and Stress Treatments}

Seedlings of 'BARI Piaj- 3' were used as plant material for stress responses. Onion bulb was used for GST purification. One month old seedlings were planted in buckets in green house of Plant Breeding Division. After establishment of seedlings, $16 \mathrm{dSm}^{-1}$ were set up by adding $\mathrm{NaCl}$ solution or water for several days. Salinity level was measured by a digital EC meter (HI993310). Reaching the salinity level to $16 \mathrm{dSm}^{-1}$ was counted as stress treatment, Then $100 \mu \mathrm{M}$ of Spd were used twice daily as foliar spray. A control set was also maintained side by side. Therefore, the treatments like control, salinity and salinity were maintained. The seedlings were observed for 7 days. Data were taken from leaves after $1,3,5$ and 7 day of stress implementation.

\subsection{Determination of Protein}

The protein concentration in the leaf extracts was determined according to the method of Bradford [40] using BSA as a protein standard.

\subsection{Enzyme Extraction and Assays}

Using a pre-cooled mortar and pestle, $0.5 \mathrm{~g}$ of leaf tissue was homogenized in $1 \mathrm{ml}$ of $50 \mathrm{mM}$ ice-cold potassiumphosphate buffer ( $\mathrm{pH}$ 7.0) containing $100 \mathrm{mM} \mathrm{KCl}, 1 \mathrm{mM}$ ascorbate, $5 \mathrm{mM} \beta$-mercaptoethanol, and $10 \%(\mathrm{w} / \mathrm{v})$ glycerol. The homogenates were centrifuged at $11,500 \times \mathrm{g}$ for $10 \mathrm{~min}$, and the supernatants were used for determination of enzyme activity. All procedures were performed at $0^{\circ} \mathrm{C}$ to $4^{\circ} \mathrm{C}$.

Glutathione $S$-transferase (GST, EC: 2.5.1.18) activity was determined spectrophotometrically by the method of Rohmanet al. [41]. The reaction mixture contained $100 \mathrm{mM}$ Tris-HCl buffer (pH- 6.5), 1.5 mM GSH, 1 mM 1-chloro-2, 4-dinitrobenzene (CDNB), and enzyme solution in a final volume of $0.7 \mathrm{ml}$. The enzyme reaction was initiated by the addition of $\mathrm{CDNB}$, and the increase in absorbance was measured at $340 \mathrm{~nm}$ for $1 \mathrm{~min}$. The activity was calculated using the extinction coefficient of $9.6 \mathrm{mM}^{-1} \mathrm{~cm}^{-1}$.

Glyoxalase I (Gly-I, EC: 4.4.1.5) assay was carried out according to Yadavet al. [7]. Briefly, the assay mixture contained $100 \mathrm{mM}$ K-phosphate buffer (pH- 7.0), $15 \mathrm{mM}$ magnesium sulphate, $1.7 \mathrm{mM}$ reduced glutathione, and 3.5 $\mathrm{mM} \mathrm{MG}$ in a final volume of $0.7 \mathrm{ml}$. The reaction was started by the addition of MG, and the increase in absorbance was recorded at $240 \mathrm{~nm}$ for $1 \mathrm{~min}$. The activity was calculated using the extinction coefficient of $3.37 \mathrm{mM}^{-1} \mathrm{~cm}^{-1}$.

Glyoxalase II (Gly-II, EC: 3.1.2.6) activity was determined according to the method of Principatoet al. [42] by monitoring the formation of GSH at $412 \mathrm{~nm}$ for $1 \mathrm{~min}$. The reaction mixture contained $100 \mathrm{mM}$ Tris- $\mathrm{HCl}$ buffer $(\mathrm{pH}-$ 
7.2), $0.2 \mathrm{mM}$ DTNB, and $1 \mathrm{mMSLG}$ in a final volume of 1 $\mathrm{ml}$. The reaction was started by the addition of SLG, and the activity was calculated using the extinction coefficient of $13.6 \mathrm{mM}^{-1} \mathrm{~cm}^{-1}$.

\subsection{Measurement of Methylglyoxal}

For methylglyoxal (MG) estimation in plants about $0.3 \mathrm{~g}$ tissue was extracted in $3 \mathrm{ml}$ of $0.5 \mathrm{M}$ perchloric acid. After incubating for $15 \mathrm{~min}$ on ice, the mixture was centrifuged at $4^{\circ} \mathrm{C}$ at $11,000 \times \mathrm{g}$ for $10 \mathrm{~min}$. A colored supernatant was obtained in some plant extracts that was decolorized by adding charcoal $\left(10 \mathrm{mgml}^{-1}\right)$, kept for $15 \mathrm{~min}$ at room temperature, and centrifuged at $11,000 \times \mathrm{g}$ for $10 \mathrm{~min}$. Before using this supernatant for MG assay, it was neutralized by keeping for $15 \mathrm{~min}$ with saturated solution of potassium carbonate at room temperature and centrifuged again at $11,000 \times \mathrm{g}$ for $10 \mathrm{~min}$. Neutralized supernatant was used for MG estimation following the method of Rohman et al. [43] by using $\mathrm{N}$-acetyl-L-cysteine at a wavelength of $288 \mathrm{~nm}$.

\section{Results and Discussion}

\subsection{Effect of Spd on Methylglyoxal Content}

Continuous increase was observed in the content of MG in onion leaves under salinity stress (Fig. 1). After 3 day of stress, the content was significantly higher as compared to control. At 1, 3, 5 and 7 day of saline stress, MG contents increased by 38, 180, 187 and $260 \%$ over control. Application of Spd reduced the MG contents in saline treated seedlings by 21 , and $48 \%$ at 1,3 , day of stress, respectively. However, Spd failed to reduce MG at 5 and 7 day.

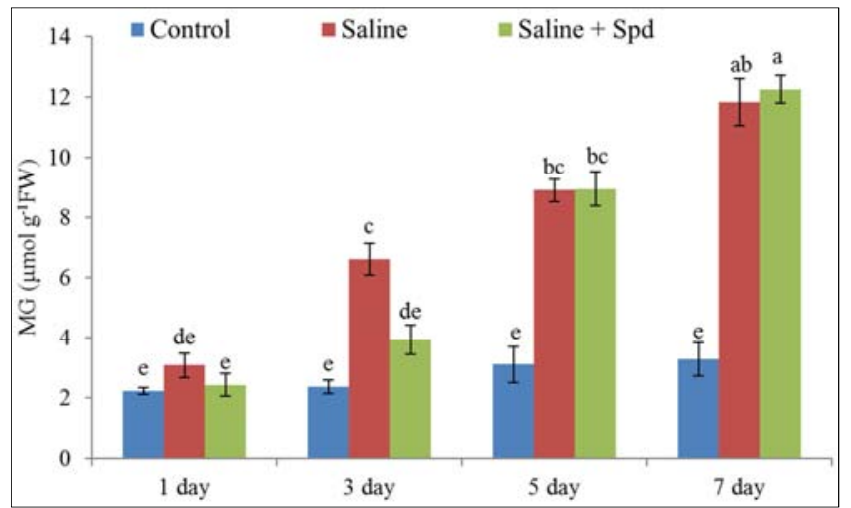

Fig. 1. Effect of Spd on Methylglyoxal content in leaves of onion seedlings under salinity stress. Values present in the bars are mean $\pm S E$. Similar letters between the bars are not significant at $5 \%$ level.

Application of Spd in onion seedlings reduced the $\mathrm{MG}$ contain (Fig. 1). However, Spd seemed to be more effective in MG detoxification system for short duration (upto 3 day) of salinity.

\subsection{Effect of Spd on Detoxification Enzyme}

Salinity stress increased the Gly-I activity gradually upto 5 day of stress (Fig. 4.18). Salinity increased the activity by 3 ,
25,41 and $9 \%$ over salinity at 1, 3, 5 and 7 day after stress implementation, respectively. Notably, in application of Spd, the activity increased at 3 day salinity stress. However, Spd decreased the activity by 16 and $9 \%$ as compared to the activity level under salinity.

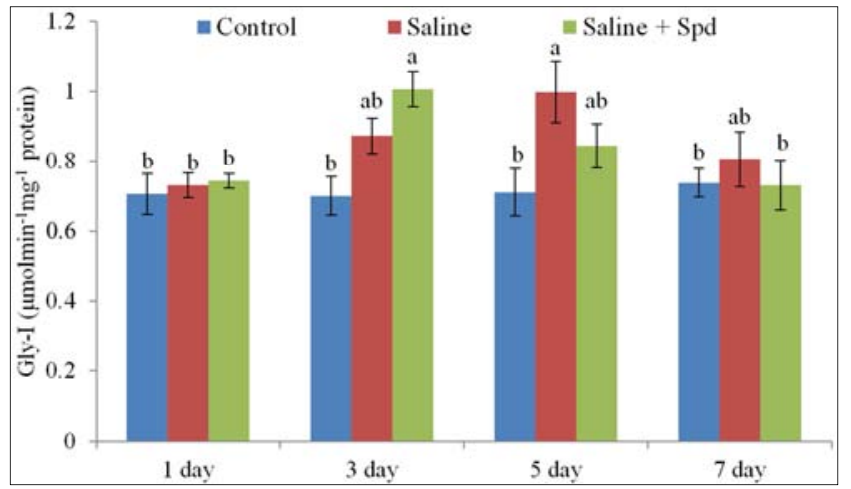

Fig. 2. Effect of Spd on activity of Gly-I in leaves of onion seedlings under salinity stress. Values present in the bars are mean $\pm S E$. Similar letters between the bars are not significant at $5 \%$ level.

Salinity stress increased the Gly-I activity gradually upto 5 day of stress (Fig. 2). Salinity increased the activity by 3, 25, 41 and $9 \%$ over salinity at $1,3,5$ and 7 day after stress implementation, respectively. Notably, in application of Spd, the activity increased at 3 day salinity stress. However, Spd decreased the activity by 16 and $9 \%$ at 5 and 7 day, respectively, as compared to the activity level under salinity.

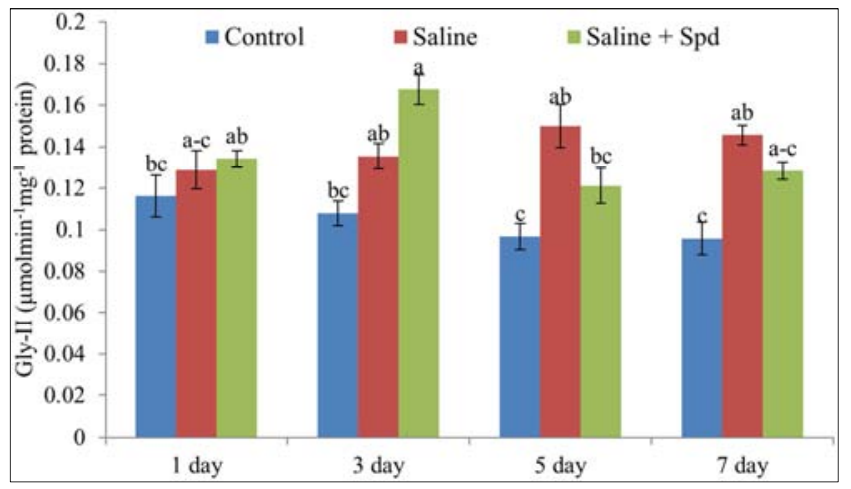

Fig. 3. Effect of Spd on activity of Gly-II in leaves of onion seedlings under salinity stress. Values present in the bars are mean $\pm S E$. Similar letters between the bars are not significant at $5 \%$ level.

Saline stress increased the activity of Gly-II, where the highest activity was found at 5 day salinity stress (Fig. 3). Salinity increased the activity by $11,26,55$ and $52 \%$ over control at 1, 3, 5 and 7 day of stress, respectively. It was important that application of Spd increased the activity in the early stage of stress, while 4 and $24 \%$ higher activity was increased at 1 and 3 day of saline stress, respectively, over salinity. Spd decreased the activity by 19 and $12 \%$ in leaves at 5 and 7 day of stress, respectively, over salinity without Spd.

The glyoxalase system consists of two enzymes (Gly-I and Gly-II) acts to convert the potential cytotoxic MG to nontoxic hydroxyacids such as lactate. Gly-I use GSH to convert 
MG to S-D-lactoyl glutathione, while the hydrolytic reaction catalyzed by Gly-II liberates the lactic acid and free GSH [44]. In several plant species, upregulation or overexpression of these enzymes increases tolerance to abiotic stresses [24, $45,46]$. Under salinity stress, upto 5 day of stress, Gly-I and Gly-II activities increased and decreased thereafter (Fig. 2, 3). However, the increases in Gly-I and Gly-II activities in salinity stressed onion seedlings suggested that the detoxification of MG via the glyoxalase system as both Gly-I and Gly-II increased concomitantly with lower contents of MG. The higher GSH level with higher Gly-I and Gly-II activities with Spd suggested the evidence for protective role of Spd for glyoxalase system for conferring saline stress tolerance in onion leaves. This tolerance might be via proline accumulation, because proline was reported to maintain higher glyoxalases and GSH in other plant species [43, 46].

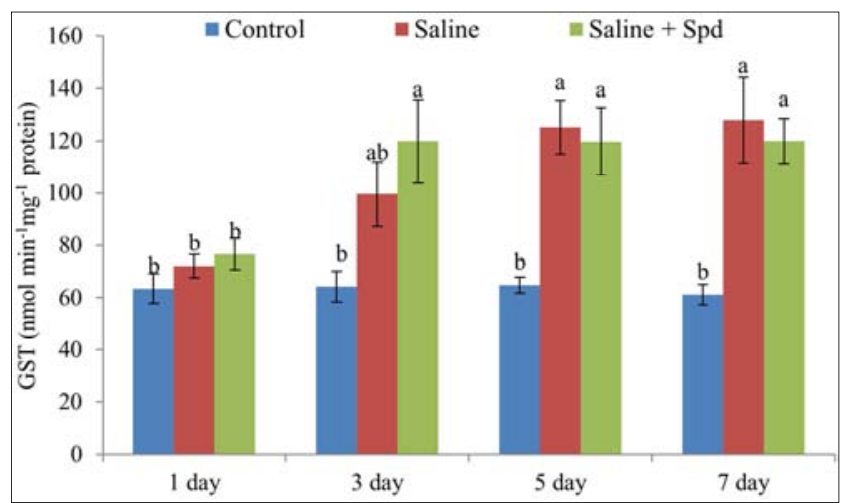

Fig. 4. Effect of Spd on activity of Glutathione S-transferase in leaves of onion seedlings under salinity stress. Values present in the bars are mean \pm SE. Similar letters between the bars are not significant at $5 \%$ level.

Remarkable increase was observed in GST activity in leaves onion seedlings under salinity stress, where the activities increased gradually with stress duration (Fig. 4). Salinity increased the activity by $14,55,93$ and $109 \%$ over control at 1 , 3,5 and 7 day after stress implementation, respectively. Application of Spd increased the activity in the early stages of stress, while 6 and $21 \%$ higher activity was increased at 1 and 3 day of salt stress, respectively over salinity. Spd decreased the activity slightly (4 and $6 \%$ ) at 5 and 7 day of stress, respectively, in salinity stressed seedlings.

The GST activity increased under salinity stress in presence or absence of Spd (Fig. 4). Increased activity of GST in onion leaves under salinity stress can participate in detoxification of ROS, xenobiotics, and membrane lipid peroxidation [47, 48], stabilize flavonoid or transportation them to vacuole $[41,49]$. The high GST activity might be due to regulation of flbonoid in onion ([41]. On the other hand, the increased GST activity also suggested its flavonoidbinding properties, and indirectly facilitating the vacuolar uptake of anthocyanins by preventing their oxidation and cross-linking in the cytoplasm [16]. GST also shows GPX activity which might reduce oxidative damage in onion [49].

In this study, theincreased GST suggested its biological role in stress mitigation which thrusts more research. GSTs are an ancient and diverse group of multi-functional proteins that are widely distributed amongst living organisms. Originally defined solely as enzymes that catalyze conjugation of GSH to an electrophilic substrate [16], it is now clear that GSTs catalyze a variety of reactions. Early plant GST research focused on the role of GSTs in herbicide resistance and vacuolar sequestration of anthocyanins [20]. In the present study, the induced GST activity and (Fig. 4) under salinity might play important physiological role like vacuolar sequestration of flavonoids like quercetine [50]. On the other hand, high activity might be associated with recycling and stabilizing flavonoid $[12,51]$, to protect cell from toxic effect. In addition to being induced by xenobiotic-type stresses, plant GST expression is activated by abiotic stress like chilling [52], hypoxic stress [53], dehydration [54, 55], wounding [56], pathogen attack [57], ethylene andauxin [16] $\mathrm{H}_{2} \mathrm{O}_{2}$ [58] and the defense signal salicylic acid [59]. GSTs have been shown to possess GST activity towards 4-hydroxy-2-nonenal (HNE) [60], a naturally occurring lipid peroxidation product that can cause oxidation and alkylation of proteins and DNA. Potentially, GST activity allows GSTs to detoxify electrophilic compounds by catalyzing their conjugation to GSH, while GSH peroxidase (GPX) activity allows GSTs to directly detoxify lipid and DNA peroxidation products [61]. It is also possible that the induced GST activities detoxify lipid peroxidation product or leaf senescencein onion under stress condition. The Spd boosted GST activity in the onion seedlings suggested its detoxification role by conjugation or directly detoxification via GPX activity and also vacuolar sequestration of flavonoids [51].

\section{Conclusion}

Considering the above results, salinity stress increased the content of MG as well as activities of glyoxalase and GST. Exogenous application of Spd reduces the MG content upto 3 day of stress. Activitiy of GST was also increased by Spd upto 3 day of stress. Therefore, exogenous application of Spd might confer tolerance in onion seedlings with shorter salinity.

\section{References}

[1] Demiral T, Türkan I. 2005. Comparative lipid peroxidation, antioxidant defense systems and proline content in roots of two rice cultivars differing in salt tolerance. Environ. Exp. Botany 53 (3): 247-257.

[2] Mandhania S, Madan S, Sawhney V. 2006. Antioxidant defense mechanism under salt stress in wheat seedlings. Biol. Plant 50 (2): 227-231.

[3] Misra N, Gupta AK. 2006. Interactive effects of sodium and calcium on proline metabolism in salt tolerant green gram cultivar. Am. J. Plant Physiol 1 (1): 1-12.

[4] Hasegawa PM, Bressan RA, Zhu JK, Bohnert, HJ. 2000. Plant cellular and molecular responses to high salinity. Annu. Rev. Plant Physiol. Plant Mol. Biol 51: 463-499. 
[5] Apel K, Hirt H. 2004. Reactive oxygen species: metabolism, oxidative stress, and signal transduction. Annu. Rev. Plant. Biol 55: 373-399.

[6] Yadav SK, Singla-Pareek SL, Reddy MK, Sopory SK. 2005a. Transgenic tobacco plants overexpressing glyoxalase enzymes resist an increase in methylglyoxal and maintain higher reduced glutathione levels under salinity stress. FEBS Lett 579 (27): 6265-6271.

[7] Yadav SK, Singla-Pareek SL, Ray M, Reddy MK, Sopory SK. 2005b. Methylglyoxal levels in plants under salinity stress are dependent on glyoxalase I and glutathione. Biochem. Biophys. Res. Commun 337 (1): 61-67.

[8] Noctor G, Mhamdi A, Chaouch S, Han Y, Neukermans J, Marquez-Garcia B, Queval G, Foyer CH. 2012. Glutathione in plants: an integrated overview. Plant Cell Environ 35 (2): 454484.

[9] Noctor G, Foyer CH. 1998. Ascorbate and glutathione: keeping active oxygen under control. Annu. Rev. Plant Physiol. Plant Mol. Biol 49: 249-79.

[10] Choudhury S, Panda P, Sahoo L, Panda SK. 2013. Reactive oxygen species signaling in plants under abiotic stress. Plant Signal. Behav 8 (4): e23681.

[11] Edwards R, Dixon DP. 2005. Plant glutathione transferases. In glutathione transferases and gamma-glutamyltranspeptidases (Sies, H. and Packer, L., eds). San Diego, CA: Elsevier Academic Press Inc, pp. 81169-186.

[12] Dixon DP, Steel PG, Edwards R. 2011. Roles for glutathione transferases in antioxidant recycling, Plant Signaling \& Behavior 6 (8): 1223-1227.

[13] Chi Y, Cheng Y, Vanitha J, Kumar N, Ramamoorthy R, Ramachandran S, Jiang SY. 2011. Expansion mechanisms and functional divergence of the glutathione $S$-transferase family in Sorghum and other higher plants. DNA Res 18 (1): 1-16.

[14] Chen JH, Jiang HW, Hsieh EJ, Chen HY, Chien CT, Hsieh HL, Lin TP. 2012. Drought and salt stress tolerance of an Arabidopsis glutathione $S$-transferase U17 knockout mutant are attributed to the combined effect of glutathione and abscisic acid. Plant Physiol 158 (1): 340-351.

[15] Zagorchev L, Seal CE, Kranner I, Odjakova M. 2013. A Central role for thiols in plant tolerance to abiotic stress. Int. J. Mol. Sci 14: 7405-7432.

[16] Marrs KA, Alfenito MR, Lloyd AM, Walbot V. 1995. A glutathione $S$-transferase involved in vacuolar transfer encoded by the maize gene Bronze-2. Nature 375 (6530): 397400 .

[17] Mueller LA, Goodman CD, Silady RA, Walbot V. 2000. AN9, a petunia glutathione $S$-transferaserequired for anthocyanin sequestration, is a flavonoid-binding protein. Plant Physiol 123 (4): 1561-1570.

[18] Kitamura S, Shikazono N, Tanaka A. 2004. TRANSPARENT TESTA 19 is involved in the accumulation of both anthocyanins and proanthocyanidins in Arabidopsis. Plant J 37 (1): $104-114$

[19] Alfenito MR, Souer E, Goodman CD, Buell R, Mol J, Koes R, Walbot V. 1998. Functional complementation of anthocyanin sequestration in the vacuole by widely divergent glutathione $S$-transferases. Plant Cell 10 (7): 1135-1149.
[20] Edwards R, Dixon DP, Walbot V. 2000. Plant glutathione $S$ transferases: enzymes with multiple functions in sickness and in health. Trends Plant Sci 5: 193-198.

[21] Mustafiz A, Sahoo KK, Singla-Pareek SL, Sopory SK. 2010. Metabolic engineering of glyoxalase pathway for enhancing stress tolerance in plants. Methods Mol. Biol 639: 95-118.

[22] Singla-Pareek SL, Yadav SK, Pareek A, Reddy MK, Sopory SK. 2008. Enhancing salt tolerance in a crop plant by overexpression of glyoxalase II. Transgenic Res 17 (2): 171180.

[23] Saxena M, Bisht R, Roy SD, Sopory SK, Bhalla-Sarin N. 2005. Cloning and characterization of a mitochondrial glyoxalase II from Brassica juncea that is upregulated by $\mathrm{NaCl}, \mathrm{Zn}$ and ABA. Biochem. Biophys. Res. Commun 336 (3): 813-819.

[24] Saxena M, Deb Roy S, Singla-Pareek S-L, Sopory SK, BhallaSarin N. 2011. Overexpression of the glyoxalase II gene leads to enhanced salinity tolerance in Brassica juncea. The Open Plant Sci J 5: 23-28.

[25] Martin-Tanguy J. 2001. Metabolism and function of polyamines in plants: recent development (new approaches). Plant Growth Regul 34: 135-148.

[26] Zhao, H. and Yang, H. 2008. Exogenous polyamines alleviate the lipid peroxidation induced by cadmium chloride stress in Malushupehensis. Rehd. SciHort 116: 442-7.

[27] Bouchereau A, Aziz A, Larher F, Martin-Tanguy J. 1999. Polyamines and environmental challenges: recent development. Plant Sci 140: 103-125.

[28] Alca'zar R, Marco F, Cuevas JC, Patron M, Ferrando A, Carrasco P, Tiburcio AF, Altabella T. 2006. Involvement of polyamines in plant response to abiotic stress. Biotech. Lett 28: $1867-1876$

[29] Krishnamurthy R, Bhagwat KA. 1989. Polyamines as modulators of salt tolerance in rice cultivars. Plant Physiol 91: 500-504.

[30] Langebartels C, Kerner K, Leonardi S, Schraudner M, Trost M, Heller W, Andermann HJ. 1991. Biochemical plant responses to ozone. I. Differential induction of polyamine and ethylene biosynthesis in tobacco. Plant Physiol 95: 882-889.

[31] Kurepa J, Smalle J, Montagu MV, Inzé D. 1998. Polyamines and paraquat toxicity in Arabidopsis thaliana. Plant Cell Physiol 39: 987-992.

[32] Roy M, Ghosh B. 1996. Polyamines, both common and uncommon, under heat stress in rice (Oryza sativa) callus. Plant Physiol 98: 196-200.

[33] Shen W, Nada K, Tachibana S. 2000 Involvement of polyamines in the chilling tolerance of cucumber cultivars. Plant Physiol 124: 431-439.

[34] He L, Nada K, Kasukabe Y, Tachibana S. 2002. Enhanced susceptibility of photosynthesis to low-temperature photoinhibition due to interruption of chill-induced increase of $S$-adenosylmethionine decarboxylase activity in leaves of spinach (Spinacia oleracea L.). Plant Cell Physiol 43: 196-206.

[35] Besford RT, Richardson CM, Campos JL, Tiburcio AF. 1993. Effect of polyamines on stabilization of molecular complexes in thylakoid membranes of osmotically stressed oat leaves. Planta 189: 201-206. 
[36] Nada K, Iwatani E, Doi T, Tachibana S. 2004. Effect of putrescine pretreatment to roots on growth and lactate metabolism in the root of tomato (Lycopersicum esculentum Mill.) under root-zone hypoxia. J. Jpn. Soc. Hortic. Sci 73: 337-339

[37] Roychoudhury A, Basu S, Sengupta DN. 2011. Amelioration of salinity stress by exogenously applied spermidine or spermine in three varieties of indica rice differing in their level of salt tolerance. J. Plant Physiol 168: 317-328.

[38] Kasukabe Y, He L, Nada K, Misawa S, Ihara I, Tachibana S. 2004. Overexpression of spermidinesynthase enhances tolerance to multiple environmental stresses and up-regulates the expression of various stress- regulated genes in transgenic Arabidopsis thaliana. Plant Cell Physiol 45 (6): 712-722.

[39] Hossain MD, Rohman MM, Fujita M. 2007. A Comparative investigation of glutathione $S$-transferases, glyoxalase-I and alliinase activities in different vegetable crops. J. Crop. Sci. Biotechnol 10: 21-28.

[40] Bradford MM. 1976. A rapid and sensitive method for the quantitation of microgram quantities of protein utilizing the principle of protein-dye binding. Anal. Biochem 72: 248-254.

[41] Rohman MM, Uddin S, Fujita M. 2010. Up-regulation of onion bulb glutathione $S$-transferases (GSTs) by abiotic stresses: A comparative study between two differently sensitive GSTs to their physiological inhibitors. Plant Omics J 3: 28-34.

[42] Principato GB, Rosi G, Talesa V, Govannini E, Uolila L. 1987. Purification and characterization of two forms of glyoxalase II from rat liver and brain of Wistar rats. Biochem. Biophys. Acta 911: 349-355.

[43] Rohman MM, Begum S, Talukder MZA, Akhi AH, Amiruzzaman M, Ahsan AFMS and Hossain Z. 2016. Drought sensitive maize inbred shows more oxidative damage and higher ROS scavenging enzymes, but not glyoxalases than a tolerant one at seedling stage. Plant Omics J 9 (4): 220-232.

[44] Noctor G, Gomez LA, Vanacker H, Foyer CH. 2002. Interactions between biosynthesis, comparmentation and transport in the control of glutathione homeostasis and signaling. J. Exp. Bot 53: 1283-1304.

[45] Hoque MA, Okuma E, Banu MNA, Nakamura Y, Shimoishi Y, Murata Y. 2007. Exogenous proline mitigates the detrimental effects of salt stress more than exogenous betaine by increasing antioxidant enzyme activities. J. Plant Physiol 164 (5): 553-61.

[46] Hoque MA, Banu MNA, Nakamura Y, Shimoishi Y, Murata Y. 2008. Proline and glycinebetaine enhance antioxidant defense and methylglyoxal detoxification systems and reduce $\mathrm{NaCl}-$ induced damage in cultured tobacco cells. J. Plant Physiol 165 (8): 813-824.

[47] Shalata A, Neumann PM. 2001. Exogenous ascorbic acid (vitamin C) increases resistance to salt stress and reduces lipid peroxidation. J. Exp. Bot 52: 2207-2211.
[48] Mittova V, Theodoulou FL, Kiddle G, Gomez L, Volokita M, Tal M. 2003. Co-ordinate induction of glutathione biosynthesis and glutathione metabolizing enzymes is correlated with salt tolerance. FEBS Lett 554: 417-421.

[49] Dixon DP, Skipsey M, Edwards R. 2010. Roles for glutathione transferases in plant secondary metabolism. Phytochem 71 : 338-350.

[50] Fini A, Brunetti C, Ferdinando MD, Ferrini F, Tattini. 2011. Stress-induced flavonoid biosynthesis and the antioxidant machinery of plants. Plant Signal. Behav 6 (5): 709-711.

[51] Rohman MM, Hossain MD, Suzuki T, Takada G, Fujita M. 2009. Quercetin-4'-glucoside: a physiological inhibitor of the activities of dominant glutathione $S$-transferases in onion (Allium cepa L.) bulb. Acta. Plant Physiol 31 (2): 301-309.

[52] Seppanen MM, Cardi T, Hyokki MB, Pehu E. 2000. Characterisation and expression of cold-induced glutathione $S$-transferase in freezing tolerant Solanumcommersonii, sensitive $S$. tuberosum and their interspecific somatic hybrids. Plant Sci 153 (2): 125-133.

[53] Moons A. 2003. Osgstu 3 and osgtu 4, encoding tau class glutathione $S$-transferases, are heavy metal- and hypoxic stress-induced and differentially salt stress-responsive in rice roots. FEBS Lett 553 (3): 427-432.

[54] Kiyosue T, Yamaguchi-Shinozaki K, Shinozaki K. 1993. Characterization of two cDNAs (ERD11 and ERD13) for hydration-inducible genes that encode putative glutathione $S$ transferases in Arabidopsis thaliana L. FEBS Lett 335 (2): 189-192.

[55] Bianchi MW, Roux C, Vartanian N. 2002. Drought regulation of GST8, encoding the Arabidopsis homologue of ParC/Nt107 glutathione transferase/peroxidase. Plant Physiol 116 (1): 96105 .

[56] Vollenweider S, Weber H, Stolz S, Chetelat A, Farmer EE. 2000. Fatty acid ketodienes and fatty acid ketotrienes: Michael addition acceptors that accumulate in wounded and diseased Arabidopsis leaves. Plant J 24 (4): 467-476.

[57] Mouch F, Dudler R. 1993. Differential induction of distinct glutathione- $S$-transferase of wheat by xenobiotics and by pathogen attack. Plant Physiol 102: 1193-1201.

[58] Zhou J, Goldsbrough PB. 1993. An Arabidopsis gene with homology to glutathione $S$-transferases is regulated by ethylene. Plant Mol. Biol 22: 517-523.

[59] Chen W, Chao G, Singh KB. 1996. The promoter of a $\mathrm{H}_{2} \mathrm{O}_{2}$ inducible, Arabidopsis glutathione $S$-transferase gene contains closely linked OBF- and OBP1-binding sites. Plant J 10 (6): 955-966.

[60] Gronwald JW, Plaisance KL. 1998. Isolation and characterization of glutathione $S$-transferase isozymes from sorghum. Plant Physiol 117 (3): 877-892.

[61] Marrs KA. 1996. The functions and regulation of glutathione $S$-transferases in plants. Annu. Rev. Plant Physiol. Plant Mol. Biol 47: 127-158. 